\title{
On the Impact of the View of Female Body on Female Sports after World War II*
}

\author{
Xu Chang-hong, Lv Yun, Yi Yong-jun \\ School of Physical Education, Yunnan Normal University, Kunming 650500, China
}

\begin{abstract}
Using documents, logical analysis, and changes in female social status, social roles and rights as the basis, this study divides the history of the impact of the view of female body after World War II on female sports into two phases for studying. Research shows that the development of the view of the female body can be influenced by cognitive level, social changes, cultural changes and other factors. With the development of history, the dominating view of female body shows a gradual trend from biological body view to social body view, and then to aesthetic body view. Under the influence of this trend, the number of women participating in sports increases from the minority to the majority; from few participation in sports to the participation in almost all projects, and female events are specially set according to the characteristics of the women themselves; from no women among the leaders of decision-making to increasing proportion of women. Female sports are developing from the number of women participating in sports, participation in sporting events and participation in the leadership of sports decision-making. In this development process, it not only reflects the influence of the female body view on it, but also conflicts continuously with the view of female body, thus promoting the view of female body to move toward the direction of female liberation.
\end{abstract}

KEYWORD: Female sport; Body idea; Influence

Dividing from the aspects of body's biological attribute, social attribute and mental attribute, the view of body has three dimensions including biological body view, social body view and aesthetic body view. Biological body view is the recognition of objective physical differences; social body view is the social differences established on the basis of biological differences, and social change gives different social functions to the body in different societies; aesthetic body view is cultural difference established on the basis of biological and social differences, and cultural changes lead to changes in aesthetic body view. These three are different dimensions of the body view, which cannot be separated from each other, and also have their own characteristics.[1]

This study analyzes the interactive relationship between the view of female body after World War II and female sports from the perspective of female liberation and in the discrimination of history and logic. In order to more clearly show the impact of the view of female body after World War II on female sports, based on the changes in female social status, social roles and rights, this study divides the history of the impact of the view of female body after World War II on female sports into two phases: from WWII to the late 1960s and from early 1970s until now.

\section{FROM WWII TO THE LATE 1960S,THE IMPACT OF THE VIEW OF FEMALE BODY ON FEMALE SPORTS}

\subsection{View of Female Body}

\subsubsection{Biological Body View}

Studies of genetics suggest that there are some differences between male and female physiology. In sexual differentiation and maturation process, the different chromosomes which are genetically determine the gender, sex hormones secretion which is influenced by brain affect the physiological development of the sexes and some other differentiation.

\footnotetext{
* About the author: Xu chang-hong, Doctor of Philosophy in Education, Research Direction: sports humanistic sociology.

Stage results of Chinese Ministry of Education Project (10YJC880138)
} 


\subsubsection{Social Body View}

During the World War II, women threw themselves into war service with a positive attitude. Although female employment has increased during this period, women are far from being equal with men, and on the whole, people still hold the opinion that women should focus on family after marriage. In the war, women have more opportunities to enter the society. The status of women has drawn wide attention from the international community after World War II. Women's wide participation in the job market makes the sex characteristics of most occupations become increasingly blurring, and in the eyes of the people, they have changed from the weak group which always needs men's protection to the group with independent personality and higher social value.

\subsubsection{Aesthetic Body View}

During this period, women still strive to fight for the equal rights of men. After World War II women's rights have been greatly improved, but there are no major changes in the cultural background of the whole community owing to this end, and the basic concept of gender roles still exists. Women are still passive, and are the products of patriarchal ideology shape. [2] For work and aesthetics, their body must become thick, and the beauty of female body shape in the eyes of men that can be representative of the social mainstream culture is still the curvaceous form of their body.

\subsection{Female Sports Development}

\subsubsection{Steady Growth of Female Athletes Participating in Sports}

At this period of time, there are ups and downs in absolute figure for the number of female athletes participating in the Olympic Games, but the overall trend is slow and steady growth. As the total number of athletes in the 16th Olympic Games drops significantly with respect to the previous two Olympic Games, the number of female athletes participating in the Olympic Games also declines. However, compared with the figure of $9.4 \%$ and $10.6 \%$ in the previous two Olympic Games, the proportion of female athletes is still rising, reaching $11.1 \%$ [3]. Therefore, at this stage, the number of women participating in athletic sports is in steady increase, and the proportion is also on the rise.

\subsubsection{Increase of the Participation of Women in Sports Events}

Decades after World War II, sport has become an increasingly important way to contend between eastern and western countries: sport becomes a weapon of the cold war, and the result is that every country gives special support to female sports. From
1952 onwards, with the participation of powerful Soviet female athletes in the Olympic Games, women rapidly integrate into the Olympic movement. In 1957, International Olympic Committee puts forward that all officially recognized World Championship should include female sports events. ${ }^{[4]}$

At this stage, women competition items in the Olympic Games gradually increase. In London Olympics of 1948, there are 136 events, 19 of which women can participate in, accounting for $13.9 \%$. In Tokyo Olympics of 1964, the proportion of the events participated by women has reached $20.6 \%$. Subsequently, in each session of Olympic Games, the proportion of the competition events that women participate in is over $20 \%$.

After the war, women's demands to participate in more competitions are increasing. Although there are some projects in Olympics opening to women, in quite a long time women are restricted from middledistance running. ${ }^{[5]}$ Women can only officially participate in the Olympic marathon until 1984. So far, women's struggle for full access to the Olympic Games makes a historic victory, which lays a foundation for the full and equal access to the Games. At this stage, the increase in female projects, both large and small items, accelerates.

\subsection{Impact of the View of Female Body on Female Sports}

After experiencing the Second World War, the role of women in the war is evident, and they begin to engage in the work which is originally called "male domain". After the war, they continue to receive the same rights as men in the economic sphere and political sphere, but the total male hegemonic culture does not change for this purpose.

At this stage, viewpoint that women's participation in sports activities should be restricted still exists. It persists that women should not do violent movement; otherwise it will make the appearance of masculine, likely cause the menstrual period problems, and may be dangerous for future pregnancy. This view arises with women's participation in sports. These arguments did not hinder the development of female sports for long, with changes in the view of female body, women sport has gradually broke through the field of "women domain." Female track and field sports are no longer limited to short-distance races, and the middle-distance races also appear in the Olympics. The viewpoint that women are not suitable for cooperation or participating in group events also has been discarded with women's participation in volleyball, basketball and some other group events.

Women's achievements in the race course break people's preset ideas about female body, and further promote the women's liberation footsteps. 
2 FROM EARLY 1970S UNTIL NOW, IMPACT

OF THE VIEW OF FEMALE BODY ON FEMALE SPORTS

\subsection{View of Female Body}

\subsubsection{Biological Body View}

In 1995, Edward .B. Lewis, an American geneticist who receives Nobel Prize for gene mutation study, believes that different characters of men and women are largely determined by hormones, and the hormone produced is determined by gene coding, not culture, so gene determines part of human behavior. This study further proves that there are a number of biological differences between the two sexes. At this time, the understanding of female biological body is more scientific, the objective existence of gender differences in the biological body of the two sexes is recognized, but this difference is not so great as once knew.

\subsubsection{Social Body View}

The economic status of women is improved because of work, and they are no longer in a dependent position in the family. Inspired by the women's movements worldwide, women begin to fight for the legal status of political and economical equality. And governments also set out provisions on gender equality in employment. Society acknowledges women's equal political rights and independent personality.

\subsubsection{Aesthetic Body View}

Until the 21st century, female aesthetic subject appears only slightly, and the passive situation of women creating cultures is able to change. "Feminine beauty" breaks through the male authoritarian aesthetic standard which only has the appearance as "feminine beauty", and is beyond the gender aesthetic idea which uses physical appearance to measure female value.

\subsection{Female Sports Development}

\subsubsection{Rapid Growth of the Number of Women Participating in Sports}

With the development and growth of the Olympic movement, the number of female athletes in the Olympic Games is increasing by session. In 1900, 19 women appear in the Olympic Games for the first time, only accounting for $1.1 \%$ of the total number. In the 2004 Athens Olympics, the proportion of female athletes has exceeded $40 \%$, reaching $40.8 \%$.[6]

\subsubsection{Drastic Increase of the Participation of Women in Sports Events}

During this period, female events in the Olympics grow more quickly. During 1980-1984, female events in the Olympics soar from 50 small items to 62 small items, and for the first time there has been synchronized swimming and rhythmic gymnastics which are specifically set for women. In the 1996 Atlanta Olympic Games, events for women have reached 21 major items, a total of 108 small items. In the 2000 Sydney Olympics, weightlifting, modern pentathlon and other projects are also open to female athletes. In 2004, female wrestling and saber individual project are added. Women's entering arouses update on the view of women in sports, leads to a new understanding of women's sports adaptability, and opens up broad prospects for women sports development [7].

\subsubsection{Emergence of Female in Leaders of Decision- making}

The right to participate in decision-making is the key to the development of female sports, because it is essential to create the opportunity to participate in sports as well as to decide statutes and rules of competition. After the 1980s, the reform of the Olympic Games provides opportunities for women's participation in the Olympic movement. In 1990s, the Olympic movement accelerates the pace of gender equality. The gender equality in sports management level has played a decisive role for a real change in the status of women in sports.

\subsection{Impact of the View of Female Body on Female Sports}

At this stage, people have a new understanding on the difference between the inherent potential of some athletic abilities like female morphological structure, physiological function and skills and the actual performance, and gradually change the previous understandings which exaggerate the differences between male and female athletes or pay no attention to the differences between male and female athletes. For whether women can participate in high-intensity confrontation competitions which need good stamina and ability, such as marathon, soccer, etc., people begin to look for a scientific basis. Meanwhile, some scholars ${ }^{[8]}$ refute the reasons which exclude female events from the Olympic Games, points out that the medical view is just used to maintain and prove the reasonableness of gender differences: the ethical debate of prohibiting women from participating in dangerous sports like boxing is suitable for both men and women; the reason they propose for women is cultural character rather than biology.

Female body in this phase is still under the "gaze" of men who define the female body inside aesthetic 
beauty like slim body. Admittedly, these events setting up specifically for women like gymnastics reflect women's physical beauty. However, the sports events admitted by most people in female sports conflict with this female body aesthetics. The rise of women's weightlifting has been subjected to criticism from many people, but now, the strength beauty demonstrated has also been endorsed.

\section{CONCLUSIONS}

3.1 From World War II to the 1960s, women's rights in the economic field are larger than ever before, demands on the political rights are increasing, but male hegemonic culture does not change for this purpose as a whole. With the change in the view of female body, female sport has gradually broke through the preset "female domain." Middle-distance track and field competitions and group competitions of female also appear in the Olympics.

3.2 Since the 1970s, people have a new understanding on the difference between the inherent potential of some athletic abilities like female morphological structure, physiological function and skills and the actual performance, and gradually change the previous understandings which exaggerate the differences between male and female athletes or pay no attention to the differences between male and female athletes. Under the influence of female body view, female sports change rapidly, the number of athletes participating in the competition leaps, and the number of events to attend is also unprecedented.

3.3 Development of female body view is affected by cognitive level, social change, cultural changes and other factors. With the development of history, the dominating view of female body shows a gradual trend from biological body view to social body view, and then to aesthetic body view. Under the influence of this trend, the number of women participating in sports increases from the minority to the majority; from few participation in sports to the participation in almost all projects, and female events are specially set according to the characteristics of the women themselves; from no women among the leaders of decision-making to the increasing proportion of women.

3.4 Female sports are developing from the number of women participating in sports, participation in sporting events and participation in the leadership of sports decision-making. In this development process, it not only reflects the influence of the female body view on it, but also conflicts continuously with the view of female body, thus promoting the view of female body to move toward the direction of female liberation.

\section{REFERENCES}

[1] Xu Chang-hong, Ren Hai, Lv Yun. Influence of women's body idea on female sport. Journal of Physical Education Vol.16 No.3.Mar.2009

[2] Gao Lin. Discussing Feminine Literature - Literary Selections of International Seminar of Feminine Literature at home and abroad. Beijing: Chinese Women Press, 1995.

[3] Chinese Sports Colleges and Universities Committee Judgement. Olympic Movement. Beijing: People Sports Press, 2005.

[4] Wilson, W. (1996) The IOC and the Status of Women in the Olympic Movement: 1972-1996. Research Quarterly for Exercise and Sport 67, pp.183-192.

[5] Blue, A. (1988) Faster, Higher, Further. Women's Triumphs and Disasters at the Olympics. Virago Press, London.

[6] Chinese Sports Colleges and Universities Committee Judgement. Olympic Movement. Beijing: People Sports Press, 2005.

[7] Simri, U. (1984) Frauen und Olympia: Sport und Emanzipation. In M. Blodorn (ed.) Sport und Olympische Spiele, pp. 89-104. Rororo, Reinbek bei Hamburg.

[8] Hargreavea, J. (1994) Sporting Females. Routledge, London. 